\title{
THE OCCUPATIONAL HEALTH NURSE IN NATAL
}

\section{B N HUNT AND L GRAINGER}

\section{Department of Nursing}

\section{University of Natal}

\section{NEED FOR OCCUPATIONAL HEALTH CARE}

The Commission of Enquiry on Occupational Health, appointed in 1975, published its findings in 1976. The general impression gained by members of the Commission, after a series of visits and interviews pertinent to the field, is summed up thus in the fourth chapter of the Report: Although industrialists in the Republic and the Territory of South-West Africa are aware of the workers' position, it has regrettably to be stated categorically that, except in the mining industry, industrial health not only occupies a secondary position in industry in this country, but that industrialists have put very little time, money and organisation into the prevention of occupational diseases (Erasmus 1976).

The report made various recommendations in regard to the improvement of this situation, among which are proposals for the necessity to educate and employ within industry, a cadre of industrial health staff, including industrial medical officers, professional and technical industrial hygienists, safety officers and occupational health nurses. The number of industrial health workers needed suggested the Report, should be in proportion to the number of workers employed at any one factory (Erasmus 1976).

\section{OPSOMMING}

Bedryfsgesondheidsorg is ' $n$ belangrike vraagstuk in Suid-Afrika. Ondersoek is ingestel na die rol en funksies van 28 geregistreerde verpleegkundiges in voltydse diens van 26 fabrieke in die Durban-area. Hulle is ook gevra om hul dringendste onderwysbehoeftes aan te dui.

'n Betekenisvolle bevinding was dat meer kennis oor diagnose en behandeling veral 'n behoefte was. Kundigheid oor gesondheidsvoorligting en rehabilitasie was glad nie as ' $n$ behoefte aangedui nie. Dit is 'n weerspieëling van die groot taak wat van die bedryfsverpleegkundige verwag word en die feit dat sy nie kans kry om haar unieke verpleegrol ten voile te vertolk nie.

\section{THE SURVEY}

\section{Group and method}

In 1980 , at the request of the local Occupational Health Nurse's Group and the Durban, District and Coastal Branch of the South African Nursing Association, the Department of Nursing at the University of Natal organised a continuing education course for interested registered nurses working within the occupational health field. This was a rewarding experience in that members of staff of the Nursing department had the opportunity to meet with colleagues in the industrial field. Discussion of nursing matters over the six-month period over which the course ran, made obvious the responsibility and range of work carried by these nurses.

Occupational health nurses attending this continuing education course were asked to complete a questionnaire relating to various aspects of their work, which thus reflects the work experience of 28 registered nurses employed full-time at 26 factories within the Durban area during the latter part of 1980 .

\section{Findings}

On analysing the replies it was clear that the nurse had great clinical responsibility for the health care of the worker, made greater by the fact that the vast majority of these workers have no family general practitioner and that their access to the formal health care system is mediated largely through the nurse at the place of work.

Reference to Table 1 shows that 26 factories employed a total of 81 occupational health workers, excluding medical officers; these workers included 28 registered nurses, 4 enrolled nurses, 34 nursing assistants and 15 first aiders. The 26 factories employed a total of 36916 production workers, giving an overall ratio in this sample of one registered nurse to every 1318 workers.

Twenty-one medical officers, all working in a part-time capacity, worked a total of 86 hours weekly in 21 factories; five factories had no medical officer on their establishment at all.

In thirteen factories, half of the total, there was only one staff member in the occupational health department. In each of these cases, this sole member was a registered nurse. The situation existed, therefore, that there were thirteen registered nurses caring for $32 \%$ (11 856) of the total number of production workers in the sample. These thirteen departments included those five departments who were without a medical officer on the staff.

The ratio of occupational health workers to production workers wa: very unevenly distributed. Factor: No 4 employed nine occupational 
Table 1 Full-time Occupational Workers in 26 factories in Natal

\begin{tabular}{|c|c|c|c|c|c|c|c|c|}
\hline Factory & $\begin{array}{l}\text { Type of } \\
\text { Industry }\end{array}$ & $\begin{array}{l}\text { Number of } \\
\text { Production } \\
\text { Workers } \\
\text { Employed }\end{array}$ & $\begin{array}{l}\text { Registered } \\
\text { Nurses }\end{array}$ & $\begin{array}{l}\text { Enrolled } \\
\text { Nurses }\end{array}$ & $\begin{array}{l}\text { Nursing } \\
\text { Assistants }\end{array}$ & $\begin{array}{l}\text { First } \\
\text { Aiders }\end{array}$ & $\begin{array}{l}\text { Medical } \\
\text { Officers }\end{array}$ & $\begin{array}{l}\text { Medical } \\
\text { Officer } \\
\text { Hours/Week }\end{array}$ \\
\hline 1 & Textile & 1766 & 1 & 1 & 3 & - & 1 & 5 \\
\hline 2 & Textile & 3566 & 1 & - & 7 & - & 1 & 5 \\
\hline 3 & Food & 395 & 1 & - & - & - & - & - \\
\hline 4 & Textile & 3800 & 1 & 2 & 6 & - & 1 & 4 \\
\hline 5 & Food & 800 & 1 & - & - & - & 1 & 5 \\
\hline 6 & Food & 420 & 1 & - & 3 & 3 & 1 & 3 \\
\hline 7 & Transport & 1190 & 2 & - & - & - & 1 & 10 \\
\hline 8 & Dairy & 1565 & 1 & - & - & - & - & - \\
\hline 9 & Food & 325 & 1 & - & - & - & 1 & 2 \\
\hline 10 & Rubber & 1500 & 1 & - & 2 & - & 1 & 8 \\
\hline 11 & $\begin{array}{l}\text { Retail } \\
\text { Store }\end{array}$ & 600 & 1 & - & - & - & 1 & 2 \\
\hline 12 & Textile & 4000 & 1 & 1 & 3 & 2 & 1 & 8 \\
\hline 13 & Food & 750 & 1 & - & - & - & - & - \\
\hline 14 & Food & 777 & 2 & - & - & - & 1 & 2 \\
\hline 15 & Motor & 714 & 1 & - & 1 & 1 & 1 & 5 \\
\hline 16 & Food & 1600 & 1 & - & - & - & 1 & 2 \\
\hline 17 & Food & 277 & 1 & - & - & 2 & - & - \\
\hline 18 & Chemicals & 350 & 1 & - & - & - & 1 & 1 \\
\hline 19 & Dairy & 209 & 1 & - & - & 1 & 1 & 1 \\
\hline 20 & Food & 1060 & 1 & - & - & - & 1 & 3 \\
\hline 21 & $\begin{array}{l}\text { Construc- } \\
\text { tion }\end{array}$ & 750 & 1 & - & 2 & - & 1 & 1 \\
\hline 22 & $\begin{array}{l}\text { Stevedor- } \\
\text { ing }\end{array}$ & 702 & 1 & - & - & - & - & - \\
\hline 23 & $\begin{array}{l}\text { Construc- } \\
\text { tion }\end{array}$ & 3500 & 1 & - & 6 & 5 & 1 & 10 \\
\hline 24 & Chemicals & 800 & 1 & - & - & - & 1 & 2 \\
\hline 25 & Textile & 3500 & 1 & - & - & - & 1 & 2 \\
\hline 26 & Packaging & 2000 & 1 & - & 1 & 1 & 1 & 5 \\
\hline TOTALS & & 36916 & 28 & 4 & 34 & 15 & 21 & 86 \\
\hline
\end{tabular}

health workers and a medical officer to care for 3800 production workers whereas Factory No $8 \mathrm{em}$ ployed one occupational health worker for 1565 production workers, with a medical officer available for emergencies only.

As part of the information required in the survey the nurses were asked to express what they perceived as their most pressing educational needs. It is not surprising that $21(77 \%)$ of them stated that they urgently wanted instruction in diagnostic examinations. They felt that their pressing need was to become competent in the use of the stethoscope, ophthalmoscope, the elucidation of chest and heart sounds, the identification of dermatological conditions, prescriptive knowledge in regard to everyday illnesses and so on.

Noticeable by its absence was any request for help in health educational techniques and methods; expertise in rehabilitation was not perceived as a need at all. Reference to table 2 illustrates the most important professional educational needs as identified by the occupational health nurses.

\section{Preventive care is essential}

The nurses' expressed needs, of course, reflect their daily working experience. They are carrying out a Herculean task and presumabiy scratching the tip of the iceberg. Prevention of disease is difficult at the best of times and more so when it is a highly mobile population with which one is dealing. Prevention of accidents is equally important. Matthysen in 1975 stated that before this year is over, over a quarter of a million South Africans will be victims of on-the-job accidents, serious enough to keep them away from

Table 2 Major expressed educational needs of Registered Occupational Health Nurses

1. Physical examination of worker: diagnostic techniques in regard to chest, eyes, ears.

2. Remedies for common complaints such as diarrhoea, athlete's foot.

3. Pharmacological knowledge.

4. Dermatological knowledge.

5. Hand injuries.

6. Emergency resuscitation. work for at least one full day. One hundred and ten thousand men and women will be permanently maimed; several hundred will be hurt so badly that they will never return to their jobs. More than 2000 will be killed.

The Natal Coastal branch (Kokstad to Pongola) of the National Occupational Safety Association (NOSA) reports that of the approximately one thousand industrial firms in the area, 406 submit statistics to them, giving only about $40 \%$ penetration of this area by NOSA. Of the eleven NOSA regions in South Africa, penetration is lowest in the two Natal regions (NOSA 1980).

NOSA statistics for the Natal Coastal Region during 1979-80 show 2,15 disabling injuries for every 100 workers and 21,3 non-disabling injuries for every 100 workers. El-Batani gives as one of the three main causes of accidents at work in developing countries the higher susceptibility attributable to difficulties in adapting to mechanised work and to low standards of general health (El-Batani 1981). 
These reflections increase the responsibility of the occupational health workers in Natal.

It is not suggested that the nurse is misguided to ask for training in the traditional medical field. Indeed, if she did not, one could only wonder who would provide competent health care.

\section{THE NATURE OF OCCUPA- TIONAL HEALTH NURSING Early beginnings}

Nurses have been working in industry for a long time now. Philippa Flowerday was appointed to Colman's mustard firm in Norwich, England in 1978 in order to work among the factory employees and to visit them at home when they were ill. A milestone in the recognition of the value of occupational health nursing was the widespread employment given to nurses in the British munitions factories during the 1914-18 war. The final report of the Health of Munition Workers Committee in 1918 gives a detailed account of the work of these nurses (Slaney 1982).

The idea was slower to take root in the less industrialised South Africa. Winter, in her Public Health Nursing Report in 1929, traced 12 nurses working in industry for the whole country. Natal employed one fully qualified at Match Factory, Durban, Salary: $£ 300$ per annum. Does welfare supervision, home visiting and health supervision generally, running clubs for European and Coloured girls. Employed and controlled by the firm (Winter 1929).

Formal and specific education for the occupational health nurse was initiated first in London in 1934 with a certificated course lasting one year run jointly by the College of Nursing and Bedford College (University of London). Occupational health nursing has been, and still is, an important component of our South African Community Nursing qualification, but the increasingly specialised and diverse nature of the work resulted in the South African Nursing Council instituting a formal Certificate in Occupational Health Nursing in 1981. The objectives of this course state that a registered nurse with specialised knowledge and skills in this field of nursing, must be able to (among other things) function as $a$ member of the health team concerned with occupational health; provide nursing care, taking into consideration the ecological and pre- ventive, promotive, curative and rehabilitative factors; ... provide health education for employees, their families, the community and employers; provide patient/client teaching and counselling (SANC 1981).

\section{Role and functions}

Charley discusses the particular role of the occupational health nurse and suggests that it is best defined as the application of nursing principles to the needs of the worker in his place of employment and that occupational health nursing, as such, is a specialised branch of public health nursing embracing both sociology and the prevention of occupational disease and accidents. (Charley 1978)

Occupational health nurses participating in a workshop conference in Johannesburg on the role of the occupational health nurse in South Africa were asked to identify specific components of the responsibilities of the occupational health nurse. Their conclusions in this regard were treatment of illness and injury, health supervision of workers (to include, among other aspects, rehabilitation of employees after injury or illness), health education and counselling, occupational safety and monitoring, education and training, administration and co-operation and liaison with outside agencies (Beaton).

The Royal College of Nursing's guide to an occupational health nursing service lists very similar functions as falling within the ambit of the occupational health nurse ( $R C N$ 1975). Jarman, in discussing the extruded role of the Brisith occupational health nurse, suggests that the specific nature of occupational health nursing max well be jeopardised if the nurse's work is allowed to be primarily that of doctor-cum-safety worker (Jarman 1978). Doctors and ind strial safety officers are invaluable but they are not nurses; and the nurse, by detini tion, cannot be the sole member of the occupational health team.

Beaton and Pinkney-Atkinson state that among factors identified as preventing the occupational health nurse from achieving her full potential are issues relating to the work relationship between nurses and occupational medical officers, especially on the point of part-time general practitioners working in industry and factors relating to management including expense, ignorance and organisational factors

\section{CONCLUSION}

Findings from the small study described amplify the above points. These Natal occupational health nurses appear to be fully extended, very largely engaged in doing what a full-time occupational medical officer would be doing, if he was employed. How fortunate that such a useful worker as the occupational health nurse exists and is employed in industry at all. Nevertheless, her nursing role is vitally important and that role includes time-consuming facets requiring great expertise, such as health education, counselling and rehabilitation after injury and illness, which responsibilities must take low priority in the demanding daily life of the occupational health nurse as presently constituted. The nurses themselves did not express their need for further education and practice in this regard.

The occupational health nurses, in fact, seemed to be under-estimating their importance, and as suggested by both the Erasmus Commission and Beaton and PinkneyAtkinson, may well have difficulty in establishing their roles beyond the limited concept held by some managers and medical officers. A telling point in this regard is that of the 28 nurses included in this survey, only fourteen of them were members of any factory safety committee. Fortunately the growth of lively occupational health nurses' specialised professional groups and the increasing number of registered nurses undertaking the Certificate in Occupational Health Nursing are eneouraging signs for a future in which expertise in this special field of nursing can only become more important

\section{REFEREKGES}

1. Erasmix R. (Chairman) (1976) Report of the commis gion of inquiry on occupational health. Governmen Finier. Pretoria. p.8-9 1976.

Sa thysen, H.J. (1975) Occupational safety in South Africa. Rehabilitation in SA. 19: 37-43 1975.

3. National Occupational Safety Association (1980) 29h Annual Report 1979-80

4. El-Banti, M. A in Schilling. R.S.F. (ed) Occupational health practice. London. Butterworth. p. 27-46 1981 Slaney, B.M. (1982) Occupational health nursing in Allan, P. and Jolley, M (eds). Nursing, midwifery and health visining since 1900 . London. Faber and Faber.

6. Winter, E. (1929) Public health nursing report. $S A$ Nursing Record p.304 Sept. 1929.

SA Nursing Council (1981) Directive for the cerrificate in occupational health nursing. Pretoria. SANC

8. Charley. I.H. (1978) The birth of industrial nursing. London. Bailliere Tindall.

9. Bcaton, G.R.: Pinkney-Atkinson, V. The role of the occupational health nurse in South Africa. SAMJ 56 218-220

10. Royal College of Nursing (1975) The RCN guide to an occupational health nursing servire: a handbook for employees and nurses. London, Royal College of Nursing. 11. Jarman, B. (1978) The extending role of the British occupational health nurse. Doctor? safetyworker? nurse. Joumal of Advanced Nursing 3: 189-198. 1978. 